\title{
Geochemistry of Ferriferous, High-K Calc-Alkaline Granitoids from the Banefo-Mvoutsaha Massif (NE Bafoussam), Central Domain of the Pan- African Fold Belt, Cameroon
}

\author{
Gus Djibril Kouankap Nono ${ }^{1}$, Jean Paul Nzenti ${ }^{*},{ }^{1}$, Cheo Emmanuel $\mathrm{Suh}^{2}$ and Sylvestre Ganno ${ }^{1}$ \\ ${ }^{I}$ Laboratory of Petrology and Structural Geology, Faculty of Science, University of Yaoundé I, PO Box 3412 MESSA- \\ Yaoundé, Cameroon \\ ${ }^{2}$ Economic Geology Unit, Department of Geology and Environmental Science, University of Buea, P.O. Box 63 Buea, \\ SW Province, Cameroon
}

\begin{abstract}
The ferriferous high-K calc-alkaline rocks of the Banefo-Mvoutsaha Massif, Pan-African Belt, Central Cameroon, were synkinematically emplaced in a sinistral strike-slip shear zone of Pan-African age. The rock sequences consist of orthogneises made of coarse-grained granites, quartz-monzonites, and medium- to fine-grained granodiorites, ranging from ca. 55 to 75 wt.- $\% \mathrm{SiO}_{2}$. They display characteristics of shoshonitic and high-K calc-alkaline series. Orthogneises are metaluminous to peraluminous and show characteristics of I-type granitoids from a ferriferous series. Trace element distribution patterns reveal rocks enriched in LILE when compared to HSFE and distinctively depleted in $\mathrm{Th}, \mathrm{Nb}, \mathrm{Ba}, \mathrm{Sr}, \mathrm{Ti}$ and $\mathrm{Ta}$. The data indicate that this granitic rock assemblage did not result from the simple differentiation of a common parental magma, but show that Banefo-Mvoutsaha plutonic rocks were derived from different crustal protoliths. Major and trace element composition are consistent with the magmatism which may have involved remelting of (1) a composite metagreywackes protolith in the upper crust and (2) amphibolitised high-K calc-alkaline basaltic andesites in the central domain of the PANEFB (Pan-African North Equatorial Fold Belt). The plutonic rocks of Banefo-Mvoutsaha area resemble other Neoproterozoic high-K calc-alkaline syntectonic plutons in Western Cameroon. They also display strong similarities with high-K calc-alkaline plutons of the Pernambuco shear zone in NE Brazil and Eastern Nigeria.
\end{abstract}

Keywords: Metaluminous, orthogneises, ferriferous series, syntectonic, I-type granites, high-K calc-alkaline, crustal protoliths, Pan-African fold belt, Cameroon.

\section{INTRODUCTION}

In orogenic belts, there is a strong connection between deformation, metamorphism and granite generation. Igneous and metamorphic rocks provide significant information on collisional magmatic processes within the continental lithosphere and their contribution to the intra-crustal recycling of the continental crust, and may also constrain the tectonic environment (e.g. $[1,2])$. There is general agreement that highly differentiated leucogranitic magmas (leucogranites) could be mostly related to anatectic products of metapelitic crustal sources [3-5] although the heat sources for their production have remained controversial [6]. Associated intermediate to basic plutonic rocks are typically lacking. Considering such potential implications, we report new petrographic and geochemical data on a Precambrian Banefo-Mvoutsaha granitic rock assemblage in the PanAfrican, North-Equatorial Fold Belt (PANEFB). In this study we examine the geological significance and petrogenesis of orogenic Pan-African metaluminous and ferriferous magmas from the central part of the PANEFB in Cameroon (Fig. 1). We focus on a 600 Ma rock association

*Address correspondence to this author at the Laboratory of Petrology and Structural Geology, Faculty of Science, University of Yaoundé I, PO Box 3412 MESSA-Yaoundé, Cameroon; Tel: +237 948564 73;

E-mail: jnzenti@yahoo.com from the Banefo-Mvoutsaha Massif, central part of central Cameroon, and compare it with similar rock types studied in this region. The good exposure of apparently co-magmatic metaluminous and potassic rocks spanning a continuous range of chemical compositions (ca. 55 to 75 wt- $\% \mathrm{SiO}_{2}$ ) makes the Banefo-Mvoutsaha Massif a key site to study the formation of orogenic ferriferous, metaluminous, calcalkaline magmas in this part of the PANEFB. We use major and trace element geochemistry to constrain the petrogenesis of the Banefo-Mvoutsaha rocks.

\section{REGIONAL GEOLOGICAL SETTING}

The Mvoutsaha Massif is located in the eastern central part of the central domain of the PANEFB in Cameroon (Fig. 1). The PANEFB or Central African Orogen is a major Neoproterozoic Orogen linked to the Trans-Saharan Belt of western Africa and to the Brasiliano Orogen of NE Brazil. In Cameroon, the Pan-African fold belt, which is partly covered by basalts and trachytes of Tertiary to Recent age, is made up of three domains [7-12]. These are from South to North (Fig. 1): (i) the Southern domain comprise Neoproterozoic metasedimentary units, such as the Yaoundé, Mbalmayo and Ntui-Betamba series. The protoliths of these units were deposited in a passive margin environment at the northern edge of the Congo Craton and were metamorphosed under high $\mathrm{P}$ conditions $\left(\mathrm{T}=750-800^{\circ} \mathrm{C}, \mathrm{P}=0.9-1.3 \mathrm{GPa}\right)$ at 
(a)

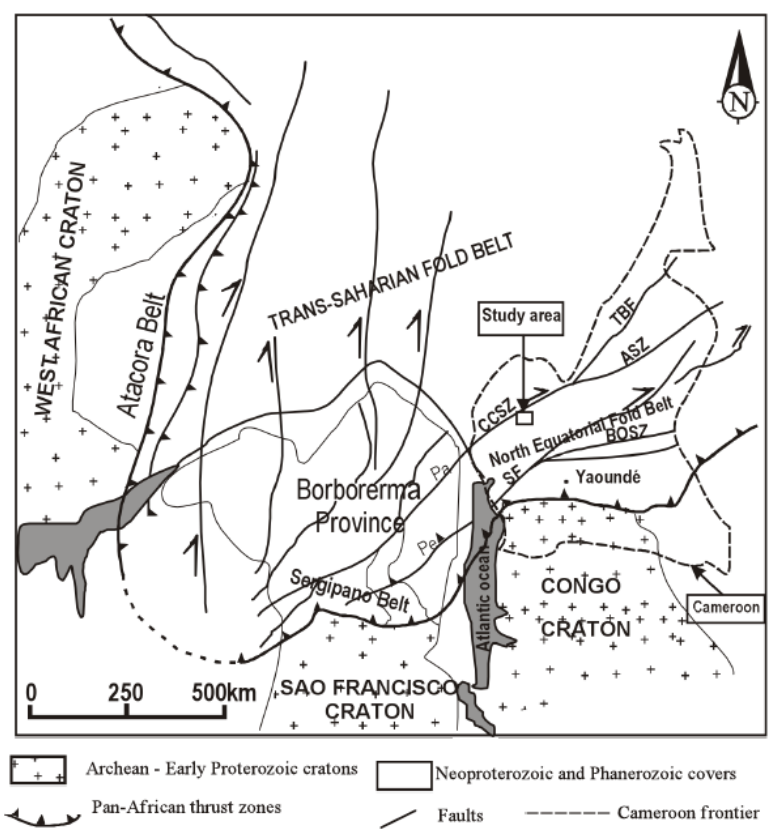

(b)

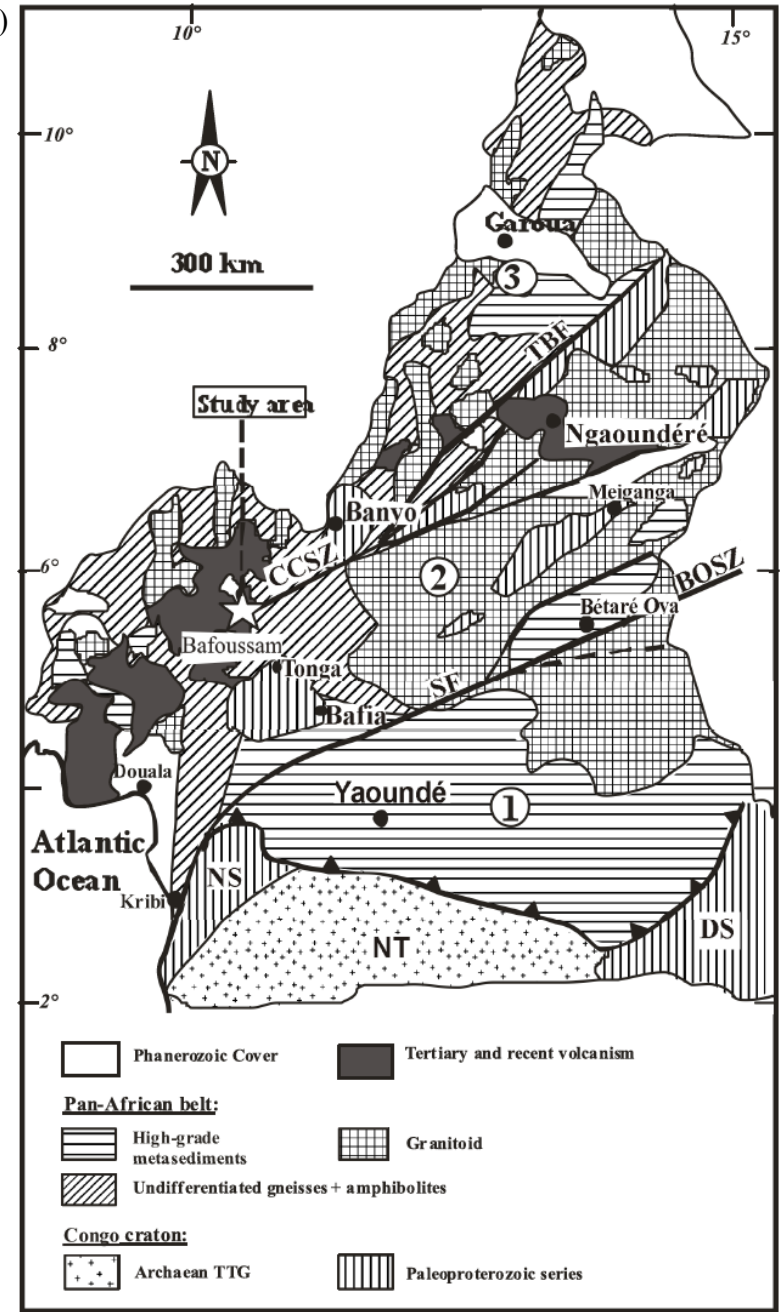

Fig. (1). (a) Geological reconstruction of Africa and NE Brazil for the Late Precambrian after [18]. CCSZ: Central Cameroon Shear Zone; PF: Pernambuco Shear Zone; SF: Sanaga Fault; TBF: Tibati-Banyo Fault. (b) Geological map of Cameroon with the three main domains of the Pan-African North-Equatorial Fold Belt modified from [7, 9, 10, and 11]: (1) southern domain corresponding to the Yaoundé series thrust on the Congo Craton, (2) central domain, (3) northern domain; granitoids suites are not further distinguished. CCSZ: Central Cameroon Shear Zone; DS: Dja series; NS: Nyong series; NT: Ntem complex; SF: Sanaga Fault; TBF: Tibati-Banyo Fault. Location of study area is marked by a square in $\mathbf{1 A}$ and star in $\mathbf{1 B}$. 
$616 \mathrm{Ma}[10,13]$. A Pan-African meta-igneous rock assemblage comprising alkaline ultramafic to metagabbros and amphibole-bearing alkaline orthogneisses [10, 14] was also recognised in association with these Neoproterozoic units. The rocks of this Southern domain were thrusted onto the Archean Congo Craton towards the South $[15,16]$. The thrust extends eastwards, forming the Oubanguides Nappe in the Republic of Central Africa. (ii) The central domain is situated between the Sanaga fault to the south and the TibatiBanyo fault (Fig. 1) to the north [17]. These large, NEstriking transcurent faults, as well as the Adamaoua fault inside the central domain, are regarded as possible prolongations of the major shear zones of NE Brazil in a predrift Gondwana reconstruction [18]. This central domain consists of an assembly of fragments of Paleoproterozoic continental crust recrystallized under high-grade granulite facies $\left(850-900^{\circ} \mathrm{C}, 1-1.2 \mathrm{GPa}\right)$ at ca $2100 \mathrm{Ma}[11,12,19]$ intruded by widespread Neoproterozoic syntectonic plutonic rocks of high-K, calc-alkaline affinities [7, 9, 20-26]. The study area belongs to the eastern central part of the central domain (Fig. 1, 2). (iii) The Northern domain consists of restricted $830 \mathrm{Ma}$ metavolcanics of tholeiitic and alkaline affinities associated with metasediments (Poli series) and of widespread $630-660 \mathrm{Ma}$ calc-alkaline orthogneisses interpreted as a major episode of accretion [27]. A Paleoproterozoic crustal source in this region is attested by the presence, in the orthogneisses, of $2 \mathrm{Ga}$ old inherited zircons in the orthogneisses [27, 28].

\section{GEOLOGY OF THE BANEFO-MVOUTSAHA MASSIF}

The Banefo-Mvoutsaha Massif comprises neoproterozoic magmatic rocks and migmatites [29] (Fig. 2, Geological map). It is a $\mathrm{N} 70^{\circ} \mathrm{E}$ elongated Massif, which comprises more or less orthogneissified high-K calc-alkaline granitoids, which crop close to the Cameroon Central Shear Zone (CCSZ). The granitoids are intruded as a series of sheets (Fig. 3) showing contacts generally strike-parallel to the main mylonitic foliation observed in the shear zone. The massif is a single geomorphologic unit, poorly surveyed and without previous geochemical studies; but for a few geochronological data indicating U-Pb zircon age of $602 \pm$ 1.4 Ma for the coarse-grained orthogneisses [21]. The Banefo-Mvoutsaha Massif comprises Neoproterozoic magmatic rocks and migmatites [29]. The granitoids are intruded as a series of sheets (Fig. 3) with the contact generally striking parallel to the main mylonitic foliation in the shear zone.

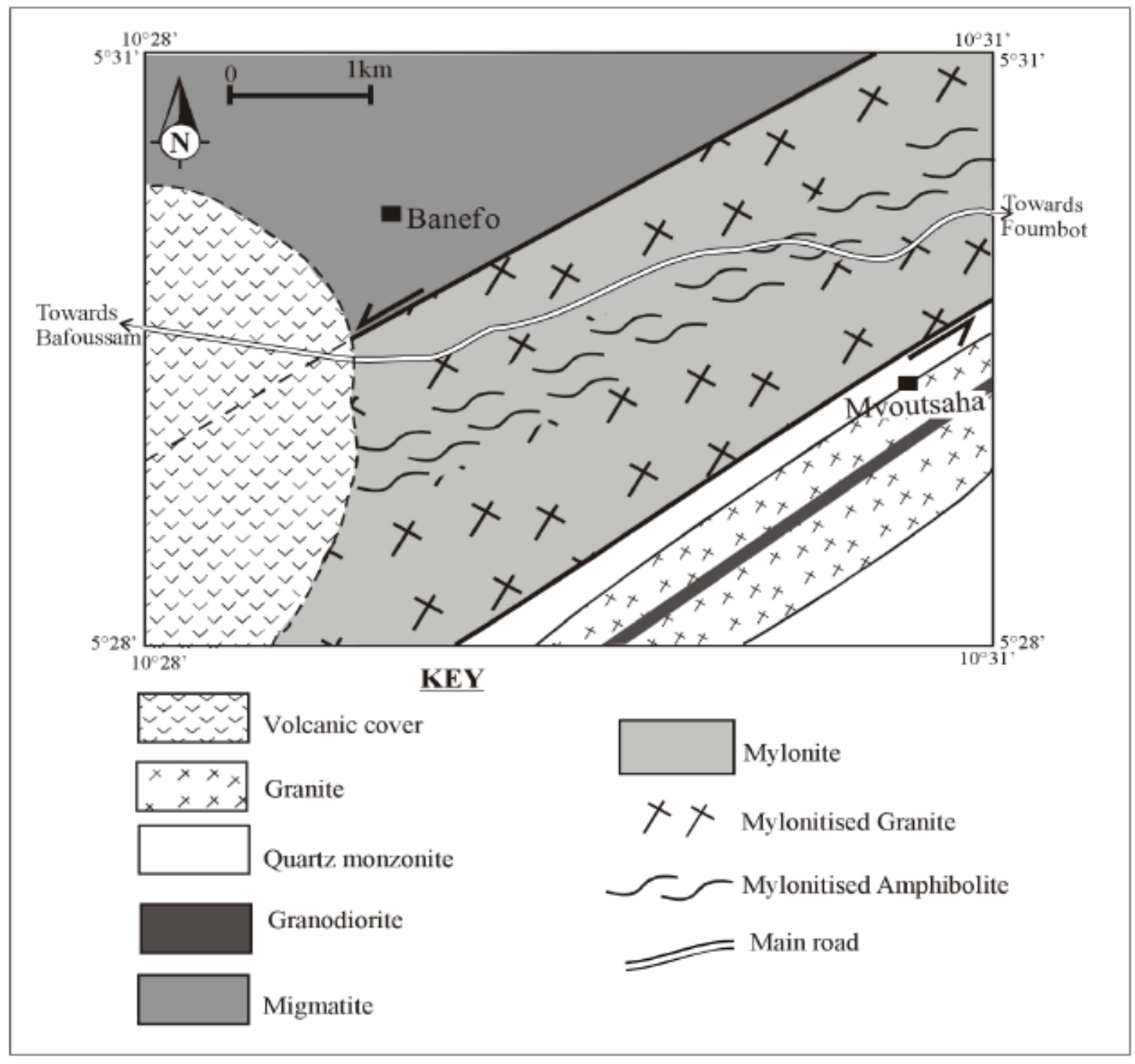

Fig. (2). Geological map of the Banefo-Mvoutsaha Massif. 

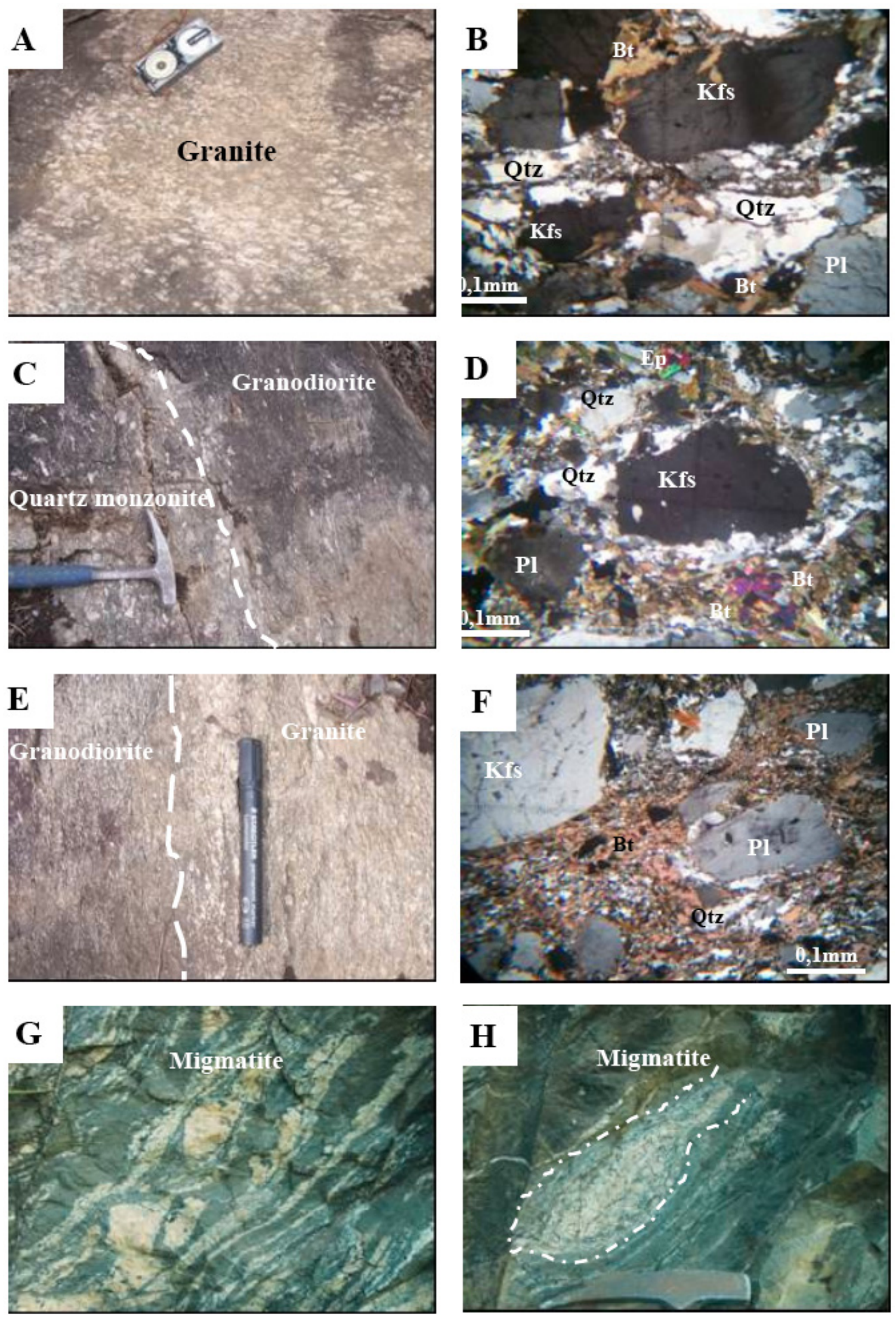

Fig. (3). Field aspects and photomicrographs of granitoids. (A) Coarse-grained granite with pink feldspar phenocrysts. (B) Granite photomicrograph; (C) Contact between the granite and quartz monzonite denoted by white broken line. (D) Quartz monzonite photomicrograph. (E) Contact between the quartz granodiorite and granite shown by broken line; (F) photomicrograph of granodiorite; (G, H): Pictures of the migmatite. 
The orthogneisses contain veins of fine-grained granites which are cross cut by the mylonitic foliation. These finegrained granites are light in colour than the host rock but less deformed, and show aplitic texture. The mineral composition is the same as in the host granite.

The granitoids grade into migmatitic gneisses and all of them present similar deformational features, as well as the same structural patterns. Moreover, enclaves of the migmatitic gneisses are observed in the granitoids. The above field characteristics point to a probable granitoids syntectonic intrusion.

\section{ANALYTICAL METHODS}

Twenty four representative samples were sent to commercial ACME Analytical Laboratories Ltd, Vancouver, Canada for whole rock chemical analysis. Representative Major and trace elements data of granitoids from the BanefoMvoutsaha massif are listed in Table 1. Whole rock analyses for major and trace elements were carried out by InductivelyCoupled Plasma Mass Spectrometry (ICP-MS) from pulps. $0.2 \mathrm{~g}$ of rock powder was fused with $1.5 \mathrm{~g} \mathrm{LiBO}_{2}$ and then dissolved in 100MM3 $5 \% \mathrm{HNO}_{3}$. The REE (rare earth element) contents were determined by ICP-MS from pulps after $0.25 \mathrm{~g}$ rock-powder was dissolved with 4 acid digestions. Analytical precisions vary from $0.1 \%$ to $0.04 \%$ for major elements; from 0.1 to $0.5 \mathrm{ppm}$ for trace elements; and from 0.01 to $0.5 \mathrm{ppm}$ for rare earth elements.

\section{PETROGRAPHY}

We use the $\mathrm{P}=\mathrm{K}-(\mathrm{Na}+\mathrm{Ca})$ vs $\mathrm{Q}=\mathrm{Si} / 3-$ $(\mathrm{K}+\mathrm{Na}+2 \mathrm{Ca} / 3)$ multi-cationic diagram (Fig. 4) of Debon and Le Fort [30] for chemical classification of the different petrographic types. Orthogneiss plot in the granite, quartzmonzonite and granodiorite fields.

\subsection{Granites}

The granites (Fig. 3a) are coarse-grained and inequigranular (Fig. 3a). They are composed of quartz (1525 vol.-\%), K-feldspar (12-20 vol.-\%), plagioclase (30-40 vol.-\%), biotite (10-15 vol.-\%); accessory minerals including titanite (2-4 vol.- $\%)$, zircon, apatite and ilmenite ( $\leq 2$ vol.- $\%$ ). K-feldspar shows perthitic exsolutions of albite. The crystals are subhedral; more rarely rounded and contain small inclusions of biotite flakes, euhedral plagioclase and quartz. Plagioclase occurs as partly elongated, subhedral or rounded crystals that may be aligned sub parallel to the foliation and may show undulatory extinction or kinked aspect. Biotite

Table 1. Geochemical Data of Selected Samples of Banefo-Mvoutsaha Massif. Analyses Performed at Acme Lab, Vancouver, Canada. Major Element in \%, REE and Trace Element in ppm and Au in ppb

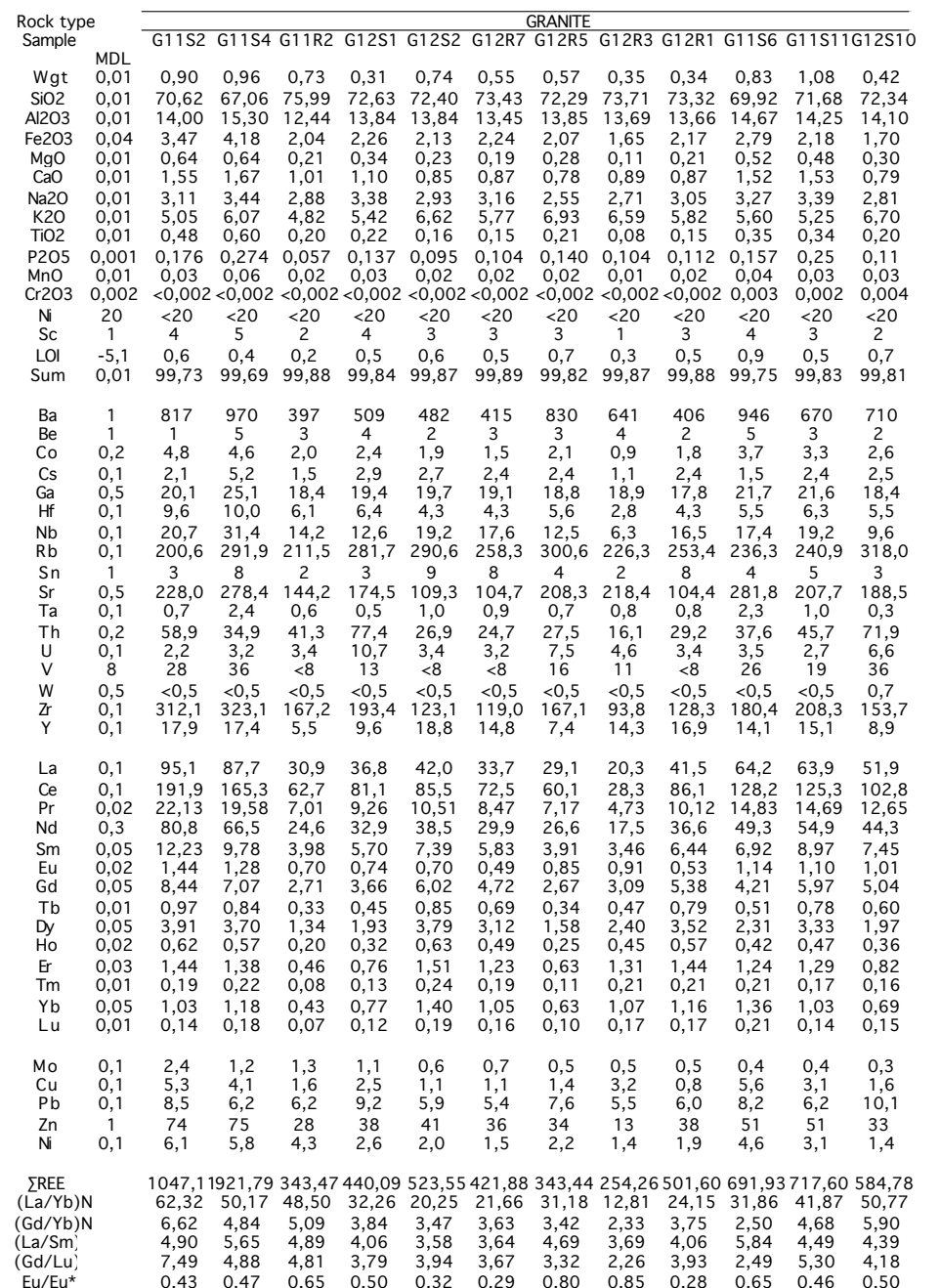

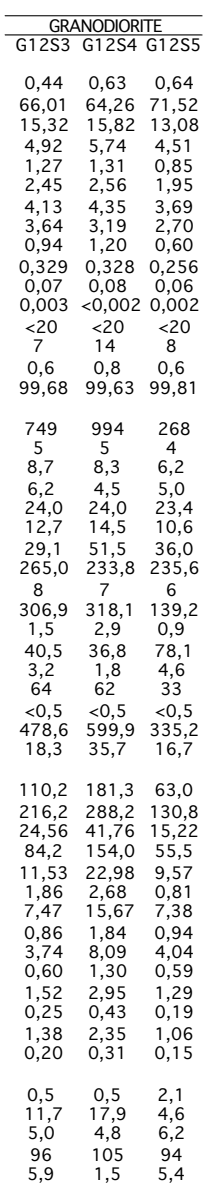

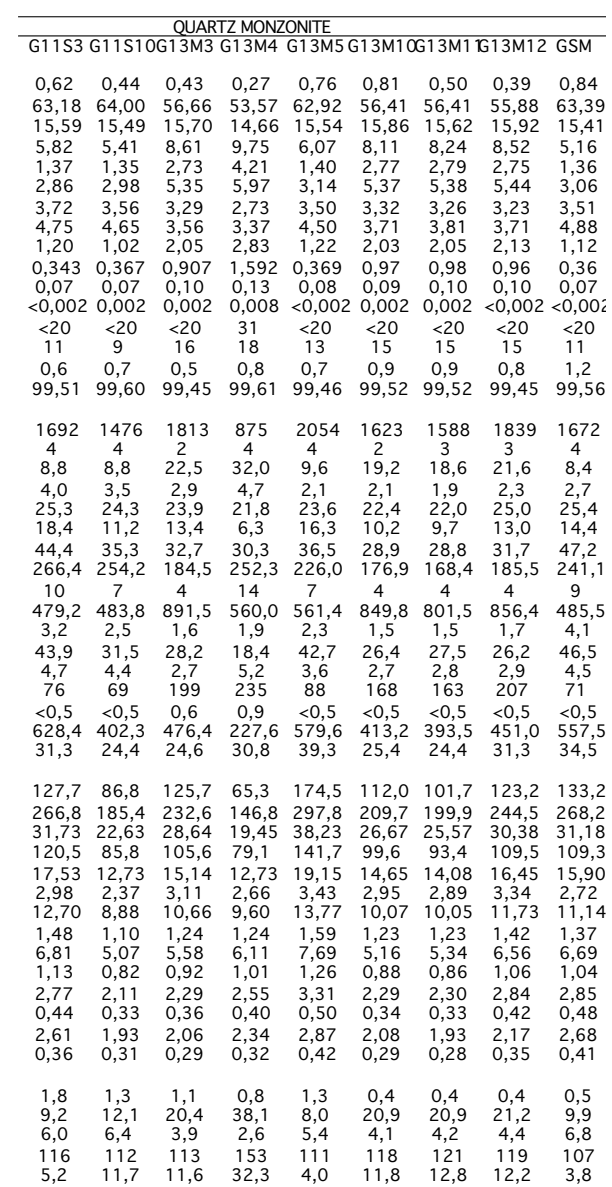

$1158,121878,85733,56$ $\begin{array}{llll}53,90 & 52,07 & 40,12\end{array}$ $\begin{array}{lll}4,37 & 5,39 & 5,63 \\ 6,02 & 4,97 & 4,14\end{array}$ \begin{tabular}{lll}
6,02 & 4,97 & 4,14 \\
4,64 & 6,28 & 6,11 \\
\hline
\end{tabular} $1508,4 \mathrm{a} 059,841375,75917,491829,031260,23184,011422,09490,3$ $\begin{array}{lllllllll}33,02 & 30,36 & 41,19 & 18,84 & 41,04 & 36,35 & 35,57 & 38,32 & 33,55\end{array}$ $\begin{array}{lllllllll}3,93 & 3,72 & 4,18 & 3,32 & 3,88 & 3,91 & 4,21 & 4,37 & 3,36 \\ 4,59 & 4,29 & 5,23 & 3,23 & 5,74 & 4,81 & 4,55 & 4,72 & 5,27\end{array}$ 
occurs as flakes of various dimensions that may be clustered, most of which have corroded margins, or forms euhedral inclusions in feldspars.

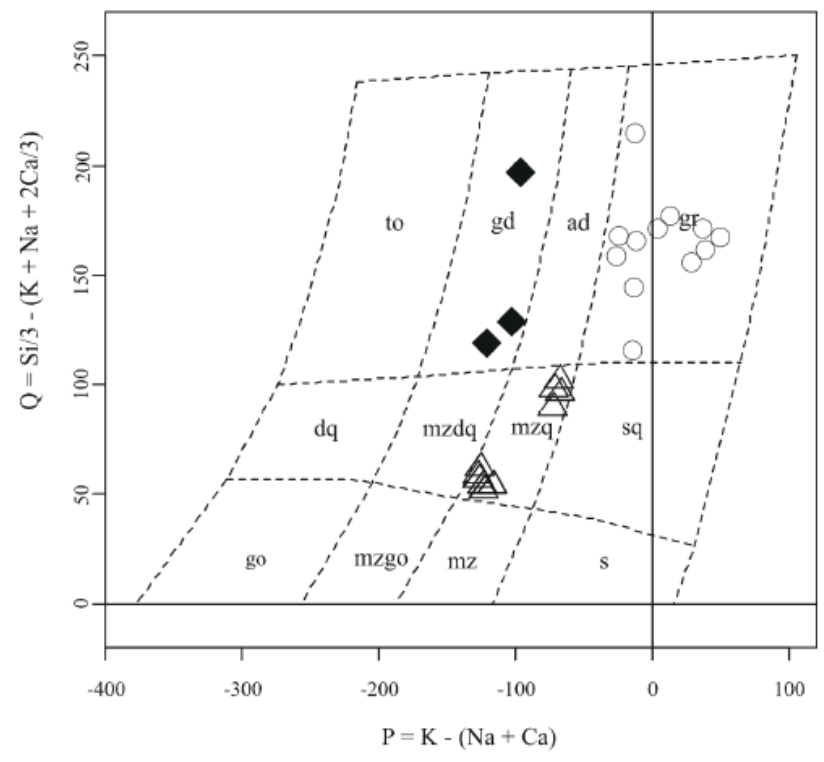

KEY: $\bigcirc$ Granites Granodiorites $\triangle$ Quartz monzonites

Fig. (4). Position of the Banefo-Mvoutsaha granitoids in the $\mathrm{Q}=$ $\mathrm{Si} / 3-(\mathrm{K}+\mathrm{Na}+2 \mathrm{Ca} / 3)$ vs $\mathrm{P}=\mathrm{K}-(\mathrm{Na}+\mathrm{Ca})$ multi-cationic diagram of Debon Le Fort (1983). go: gabbro, diorite; mzgo: monzogabbro; mz: monzonite; s: syenite; dq: qtz diorite; mzdq: qtz monzodiorite; mzq: quartz monzonite; sq: quartz syenite; to: tonalite; gd: granodiorite; ad: adamellite; gr: granite.

\subsection{Quartz-Monzonites}

The rock is dark in colour (Fig. 3c), fine- to mediumgrained showing granoblastic microstructure (Fig. 3d). The samples are rich in ferromagnesian minerals and composed of biotite (20-25 vol.-\%), amphibole (15-30 vol.- \%), pyroxene (20-35 vol.- $\%)$, quartz (2-5 vol.- $\%$ ) plagioclase and K-feldspar (15-20 vol.-\%). Accessory phases are zircon and apatite. Quartz forms elongated polycrystalline ribbons $(\leq$ $10 \mathrm{~mm}$ in the length) or elongated granoblastic aggregates. Perthitic K-feldspar exhibits sigmoid $(0.75 \times 0.5 \mathrm{~mm})$ or almond shape $(4 \times 2.5 \mathrm{~mm})$, shows perthitic exsolutions of albite and also often show extensive development of myrmekite at the grain peripheries. The crystals contain small inclusions of titanite, apatite, biotite flakes or quartz grains. Some crystals have microfractures filled by quartz. Plagioclase occurs as partly elongated, subhedral or rounded crystals that may be aligned sub parallel to the schistosity and may show undulatory extinction or deformational twinning and they are occasionally are kinked. All are rimmed by quartz aggregates. Biotite occurs as flakes of various dimensions that may be clustered, most of which derive from destabilisation of amphibole or pyroxene. Amphibole is a green hornblende with almond shape and contains small euhedral inclusions of apatite, zircon and ferriferous oxides.

\subsection{Granodiorites}

The granodiorites are fine- to medium-grained grey to yellowish grey rocks (Fig. 3e) with a heterogranular granoblastic texture (Fig. 3f). Its mineralogy is made up of quartz (20-30 vol-\%), K-feldspar (25-30 vol-\%), plagioclase (40-45 vol-\%), biotite (5-10 vol-\%), and amphibole (2-10 vol-\%). Magnetite, apatite, titanite and zircon are accessory phases. Quartz exhibits polycrystalline ribbons or single crystals with undulatory extinction. K-feldspar crystals are subhedral; more rarely rounded and contain small inclusions of amphibole and apatite grains. Some K-feldspar grains are sheared. Myrmekitic growth is common along the boundaries of K-feldspar porphyroclasts. Plagioclase is subhedral with undulatory extinction. All plagioclase crystals are rimmed by quartz aggregates. Broken crystals are also observed and the fractures are filled by recrystallized quartz. Green hornblende is not abundant and occurs as anhedral crystals associated to flakes of biotite.

\subsection{Migmatitic Gneisses}

The migmatitic gneisses are medium-grained and display millimeter to centimeter thick quartz-feldspathic layers (leucosomes) alternating with layers rich in ferromagnesian minerals, mainly biotite (melanosome). The texture of the leucosomes is granoblastic heterogranular. The mineral association is polycrystalline ribbon quartz, subhedral $\mathrm{K}$ feldspar and plagioclase, biotite flakes, pink, rounded garnet. Migmatitic gneisses (Fig. 3g, h) are closely associated with orthogneisses. The contacts between migmatitic gneisses and orthogneisses are concordant.

\section{GEOCHEMISTRY}

\subsection{Major Elements}

Major element concentrations of the Banefo-Mvoutsaha rocks are listed in Table $\mathbf{1}$. The rocks are silica-rich (with a total range of $53.57-75.99$ wt.- $\% \mathrm{SiO}_{2}$ ) and show a high-K calc-alkaline to shoshonitic affinity (Fig. 5). In major element variation diagrams (Fig. 6), the three rock types (granite, quartz-monzonite and granodiorite) form well defined clusters and, taken together define more or less welldefined trends, where $\mathrm{Al}_{2} \mathrm{O} 3, \mathrm{Fe}_{2} \mathrm{O}_{3}$ tot, $\mathrm{MgO}, \mathrm{CaO}, \mathrm{TiO}_{2}$, $\mathrm{MnO}$ and $\mathrm{P}_{2} \mathrm{O}_{5}$ concentrations decrease monotonously with

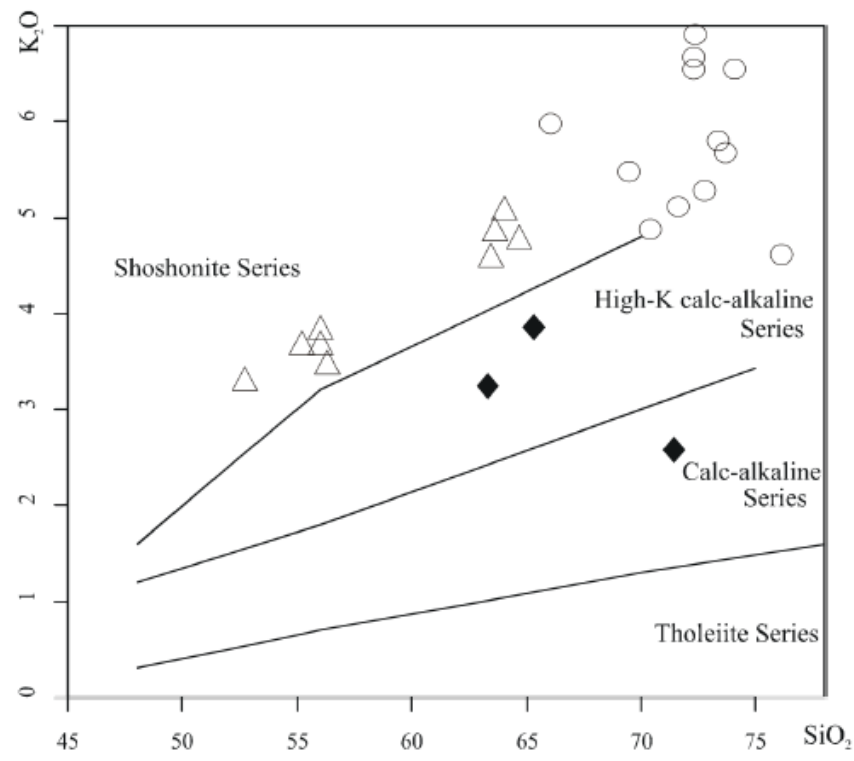

Fig. (5). $\mathrm{SiO}_{2}$ vs $\mathrm{K}_{2} \mathrm{O}$ diagram showing high- $\mathrm{K}$ calc-alkaline affinity of the Banefo-Mvoutsaha rocks, axis units are wt $\%$. Symbols as in Fig. (4). 

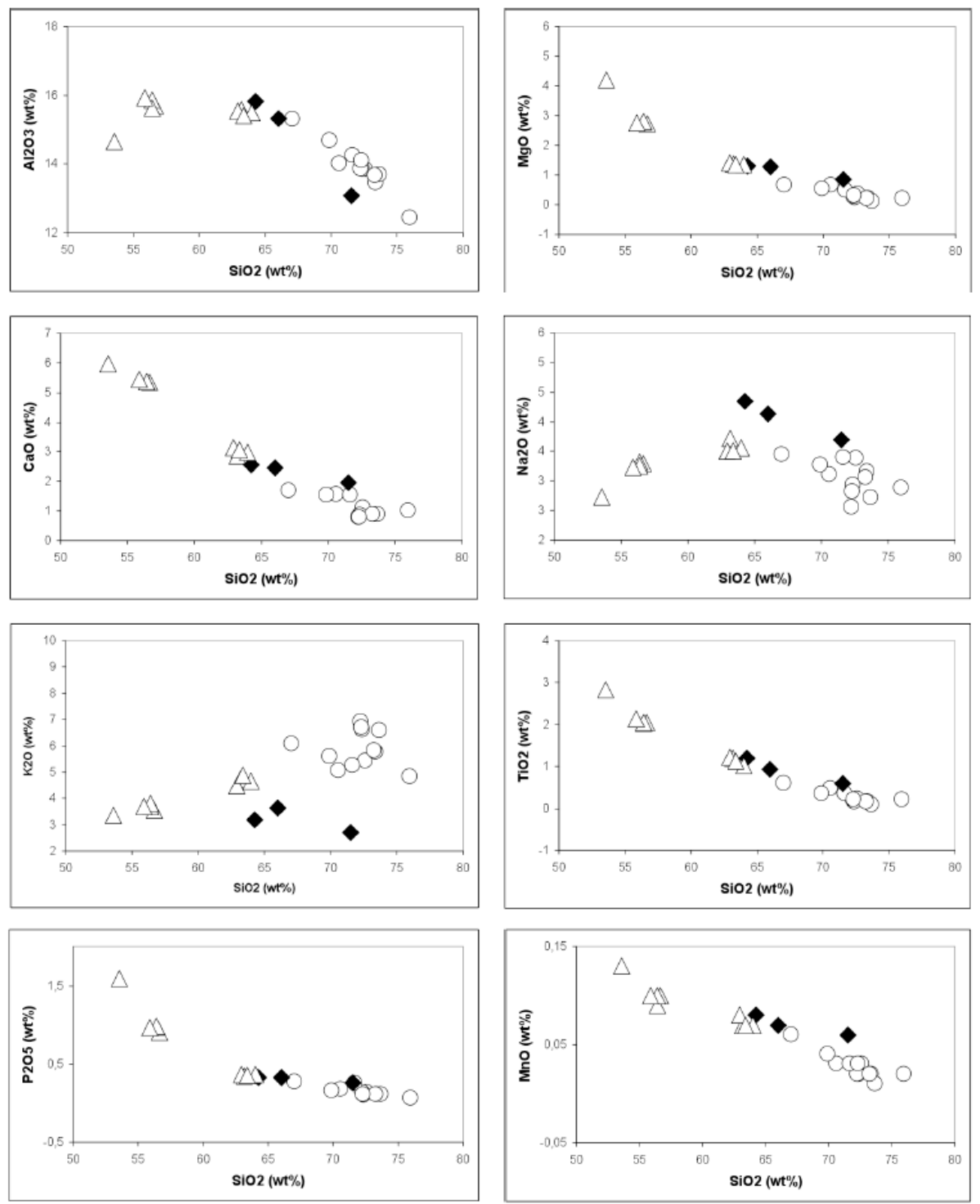

Fig. (6). Harker diagrams of selected major elements. Symbols as in Fig. (4).

increasing amount of $\mathrm{SiO}_{2}$, whereas the variation of $\mathrm{Na}_{2} \mathrm{O}$ and $\mathrm{K}_{2} \mathrm{O}$ is independent of the $\mathrm{SiO}_{2}$ content. The total alkali concentrations are uniform within each rock unit, i.e., 7.7 10.73 wt.- $\%$ in granites, $6.39-8.45$ wt.- $\%$ in granodiorites and $6.1-8.47$ wt.- $\%$ in quartz-monzonites. The granitoids are $\mathrm{K}$-rich and show $\mathrm{K}_{2} \mathrm{O} / \mathrm{Na}_{2} \mathrm{O}$ ratios ranging from 1.03 to 3.59 with lowest values in granodiorites $(0.69-0.95)$. They display characteristics of shoshonite to high-K calc-alkaline series (Fig. 5). High alkalis contents relative to $\mathrm{CaO}$ are characteristic of calc-alkalic to alkalic cordilleran granitoids according to the classification of Frost et al. (2001). When using the $\mathrm{Al}$ saturation index $\mathrm{A} / \mathrm{CNK}(=$ molar $\mathrm{Al}_{2} \mathrm{O}_{3} /\left(\mathrm{CaO}+\mathrm{Na}_{2} \mathrm{O}+\mathrm{K}_{2} \mathrm{O}\right)$, granites and granodiorites are peraluminous; quartz monzonites plot in the metaluminous field and all of them conform to I-type (Fig. 7) granitoids [31]. Using the classification of Frost et al. [32] to discriminate between ferroan granitoids and magnesian granitoids, nearly all the granitoids of the Banefo-Mvoutsaha area are ferroan (Fig. 8a) and of ferriferous field (Fig. 8b). These granitoids are similar to the other granites in the central domain of PANEFB in Cameroon [9, 20, 21, 22, 25].

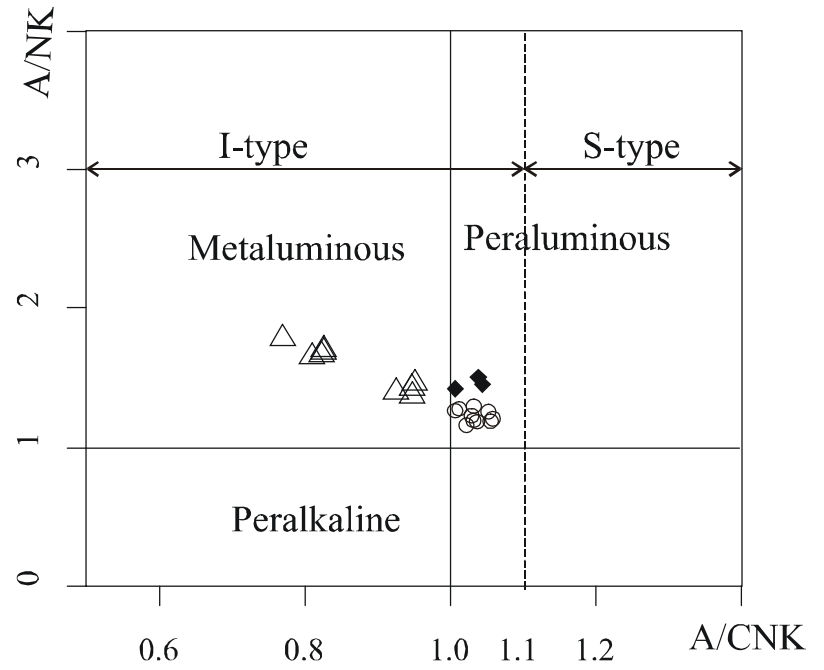

Fig. (7). Alumina index diagram (Molar $\mathrm{Al}_{2} \mathrm{O}_{3} /(\mathrm{CaO}+$ $\left.\mathrm{Na}_{2} \mathrm{O}+\mathrm{K}_{2} \mathrm{O}\right)$ vs $\left.\mathrm{Al}_{2} \mathrm{O}_{3} /\left(\mathrm{Na}_{2} \mathrm{O}+\mathrm{K}_{2} \mathrm{O}\right)\right)$ for Banefo-Mvoutsaha granites. Symbols as in Fig. (4). Boundary between I-type and Stype according to Chappell and White [31]. 

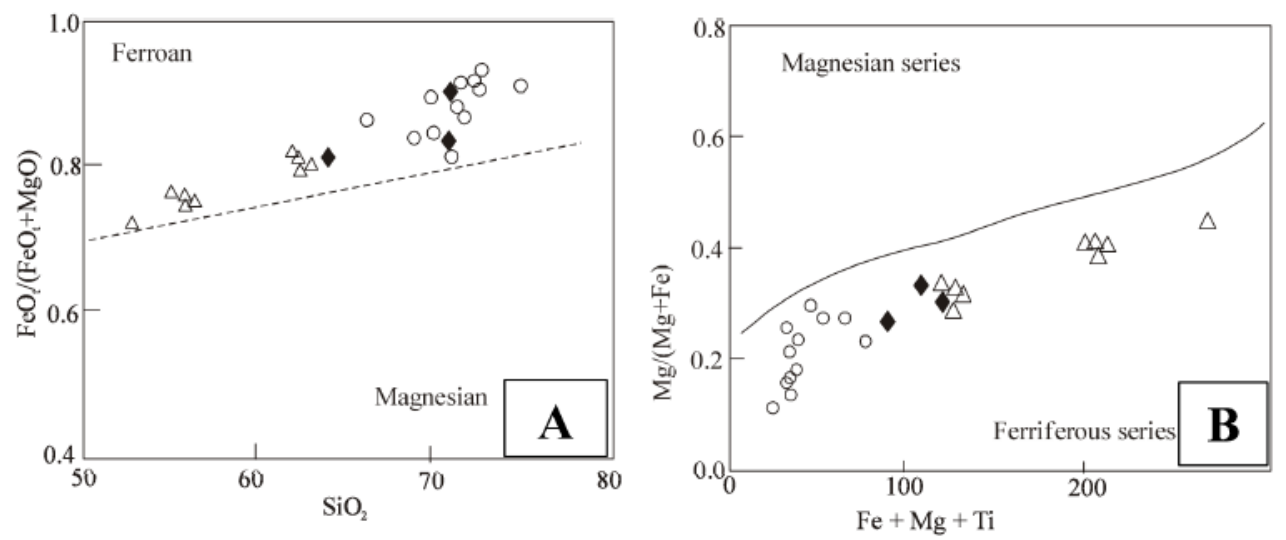

Fig. (8). (a) Position of the Mvoutsaha-Bafoussam granites in the $\mathrm{SiO}_{2} v s \mathrm{FeOt} /(\mathrm{FeOt}+\mathrm{MgO})$ diagram, axis units are wt\%. (b) $\mathrm{Fe}+\mathrm{Mg}+\mathrm{Ti}$ vs $\mathrm{Mg} / \mathrm{Mg}+\mathrm{Fe}$ diagram, axis units are millications. Symbols as in Fig. (4).

\subsection{Trace Elements}

Trace element concentrations of the Banefo-Mvoutsaha rocks are listed in Table 1. Selected elements are plotted
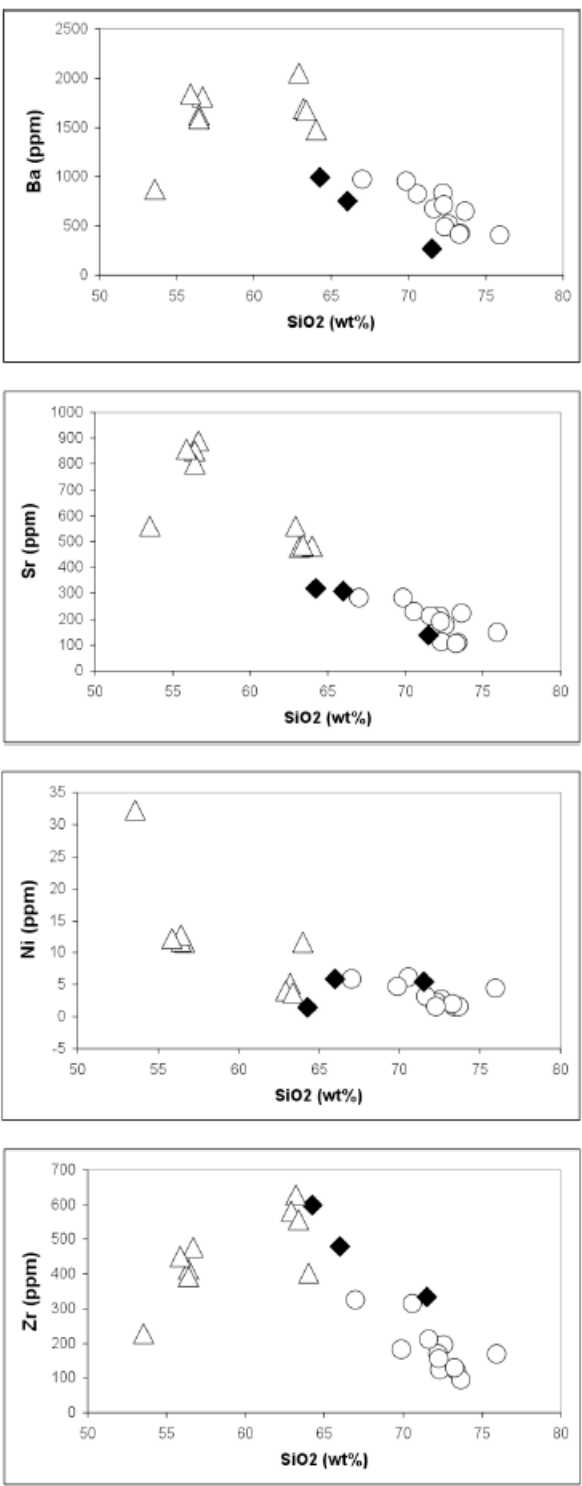

against $\mathrm{SiO}_{2}$ content in Fig. (9). Ba, Nb, Ni, Co, Sr, Zr, Zn and $\mathrm{Y}$ concentrations decrease whereas $\mathrm{Rb}$ concentrations increase with increasing $\mathrm{SiO}_{2}$ content. $\mathrm{Ba} / \mathrm{Sr}$ ratios range
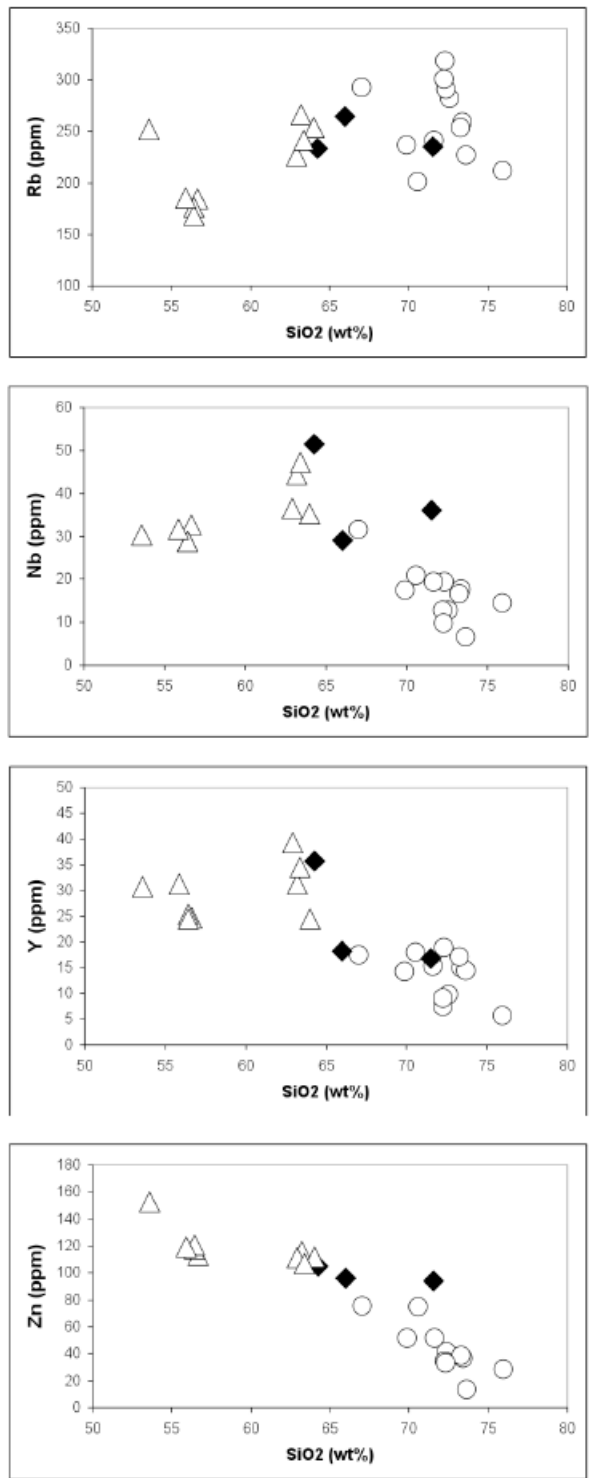

Fig. (9). Harker diagrams of selected trace elements. Symbols as in Fig. (4). 
between 1.50-4.0 and $\mathrm{Ba} / \mathrm{Rb}$ between 1.5 and $10 ; \mathrm{K} / \mathrm{Rb}$ ratios are between 115 and 805 . These values are similar to those observed in continental calc alkaline igneous suites $[33,34]$. Chondrite normalised rare earth element (REE) patterns of the Banefo-Mvoutsaha suite (Fig. 10) resemble each other, in general with a strong LREE (light rare earth element) enrichment with $\mathrm{La}_{\mathrm{N}} / \mathrm{Yb}_{\mathrm{N}}$ ratios of $6.48-62.32$ and $\mathrm{Gd}_{\mathrm{N}} / \mathrm{Yb}_{\mathrm{N}}$ ratios of $1-6.62$. Negative $\mathrm{Eu}^{*}$ anomalies are pronounced in all the rocks $\left(\mathrm{Eu} / \mathrm{Eu}^{*}=0.29-0.85\right)$. The multielement spectra (Fig. 10) of all these rocks show a distinctive depletion in $\mathrm{Ba}, \mathrm{Nb}, \mathrm{Sr}, \mathrm{P}$ and $\mathrm{Ti}$ relative to other trace elements (characteristic of calc-alkaline granites of crustal origin, [35]) and are enriched in LILE (large ion lithophile elements) and display negative anomalies in $\mathrm{Sr}, \mathrm{Ba}$ and $\mathrm{Ti}$. Distinctively higher contents of Th are observed in the rock.
These rocks display less pronounced negative anomalies in $\mathrm{Sr}$ and $\mathrm{Ti}$, and lower $\mathrm{Y}$ and $\mathrm{Yb}$ values resulting in more "fractionated" trace element distribution patterns, characteristic of calc-alkaline arc granitoids.

These granitoids are geochemically similar to those from the Eastern Nigeria [36], and Borborema Province, NE Brazil [37]: all the rocks are metaluminous to weakly peraluminous (Fig. 11), high-K calc-alkaline and shoshonitic type (Fig. 12), and they are enriched in most incompatible elements (especially for $\mathrm{K}, \mathrm{Rb}, \mathrm{Ba}$ ). Nevertheless, the $\mathrm{Fe}$ $+\mathrm{Mg}+\mathrm{Ti} v s \mathrm{Mg} /(\mathrm{Mg}+\mathrm{Fe})$ diagram (Fig. 13) points to a single difference. This figure shows a ferriferous character for the Banefo-Mvoutsaha and the Eastern Nigeria granitoids, while granitoids of the Borborema Province, NE Brazil are magnesian type.
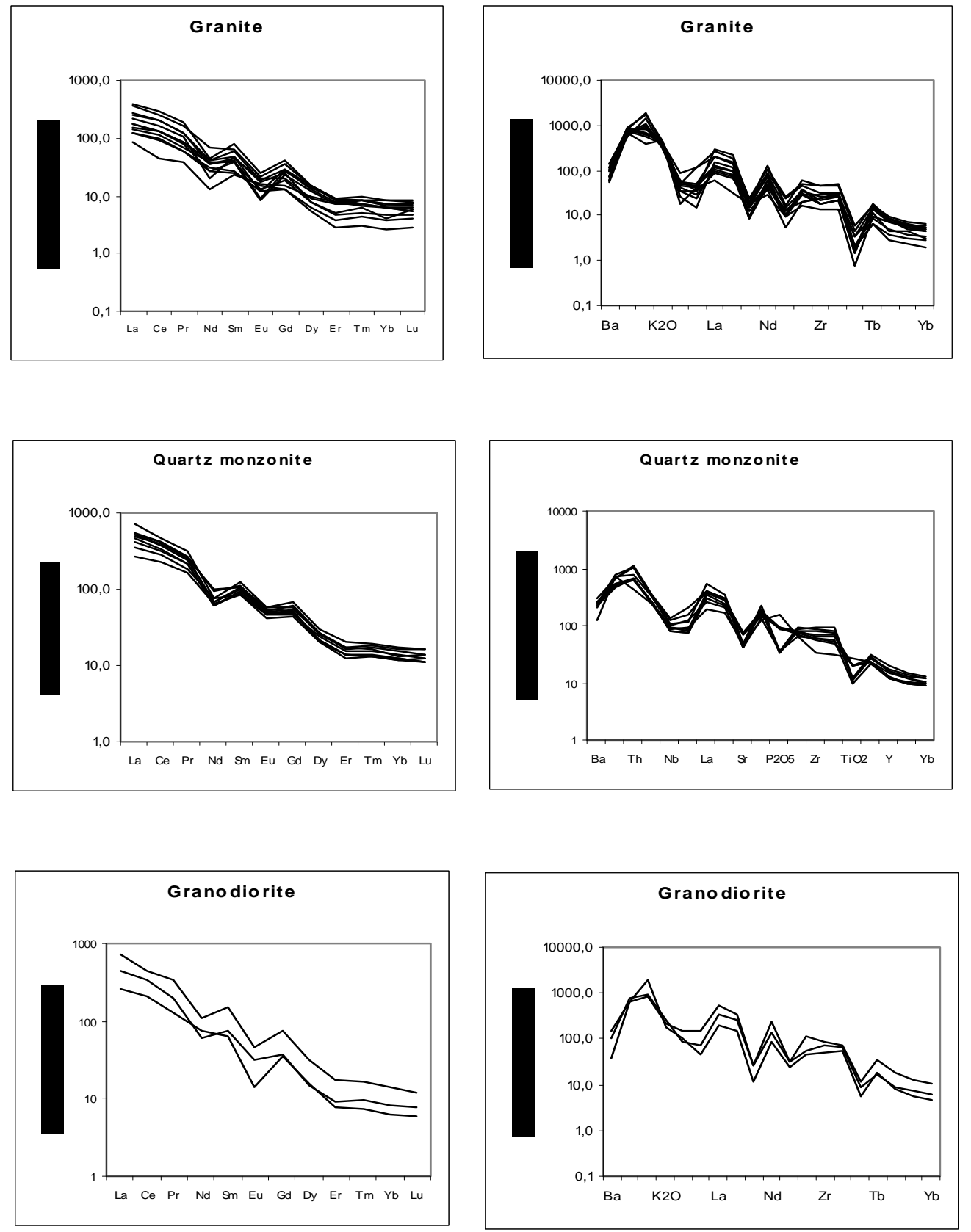

Fig. (10). Chondrite-normalized REE (the normalising values are from Evensen et al. [52]) and multi-element (Normalization values after Thompson et al. [35]) patterns for the Mvoutsaha-Bafoussam granites. 


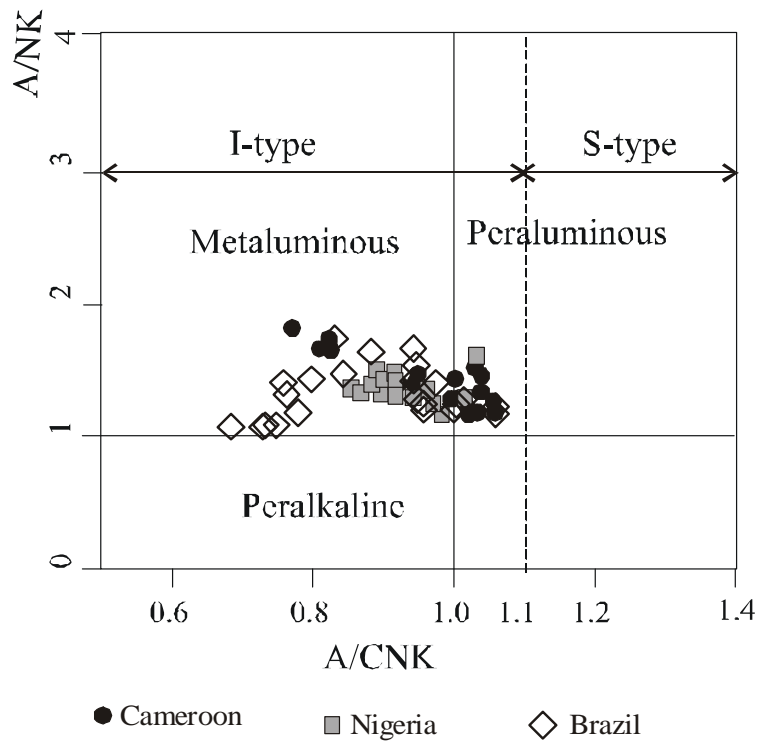

Fig. (11). Alumina index diagram (Molar $\mathrm{Al}_{2} \mathrm{O}_{3} /(\mathrm{CaO}+$ $\left.\mathrm{Na}_{2} \mathrm{O}+\mathrm{K}_{2} \mathrm{O}\right)$ vs $\left.\mathrm{Al}_{2} \mathrm{O}_{3} /\left(\mathrm{Na}_{2} \mathrm{O}+\mathrm{K}_{2} \mathrm{O}\right)\right)$ for the comparison betewen Banefo-Mvoutsaha, eastern Nigeria and NE Brazil granitoids.

\section{DISCUSSION}

\subsection{Source Rock Characteristics}

The investigated Banefo-Mvoutsaha plutonic rocks exhibit petrographical and chemical compositions characteristic of shoshonite to high-K calc-alkaline I-type granitoids [31, 38] derived from partial melting of igneous protoliths. From the several studies carried out to constrain the generation of high-K magmas in convergent tectonic settings, two main processes are commonly recognised [39]: (i) in continental arc settings, where mantle melts can be enriched by slab-derived fluids and further may become contaminated with crustal material during ascent [40]; (ii) in syn- to post-collisional settings, crustal source rocks may melt as a consequence of decompression following delamination of the lithospheric root or slab break off (e.g. $[41,42])$. The behavior of Banefo-Mvoutsaha granitoids on Harker diagrams does not indicate a whole continuous compositional variation from one group to another, but little internal compositional variation and overlap between some groups. This suggests that the compositional variability of these granitoids does not seems to be generated only by fractionation processes, but probably reflects the primary compositions of anatectic melts generated at various crustal levels.

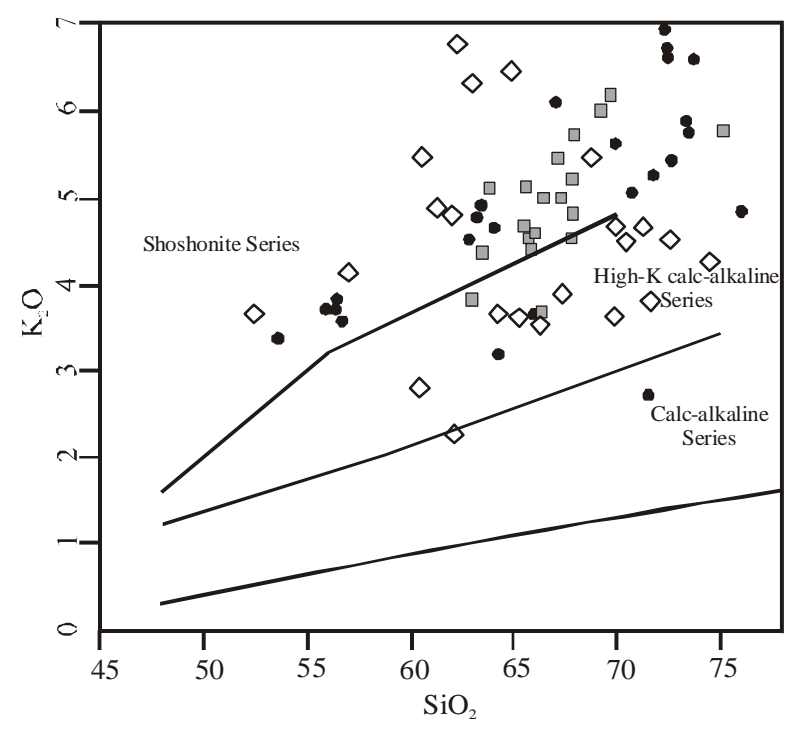

Fig. (12). $\mathrm{SiO}_{2}$ vs $\mathrm{K}_{2} \mathrm{O}$ diagram for the comparison betewen Banefo-Mvoutsaha, eastern Nigeria and NE Brazil granitoids. Units of axis are wt\%; Symbols as in Fig. (11).

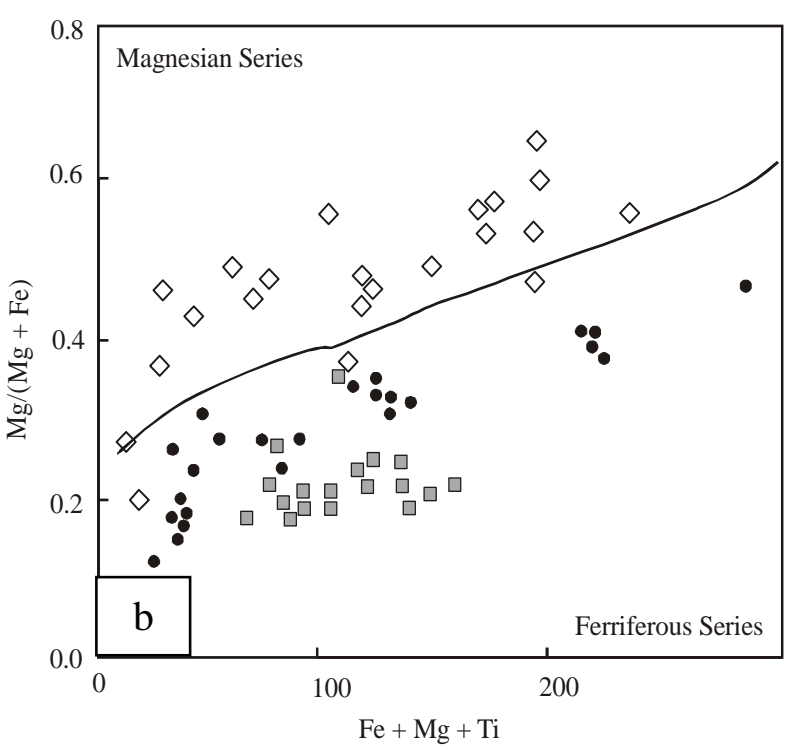

Fig. (13). Diagrams for the comparison betewen Banefo-Mvoutsaha, eastern Nigeria and $\mathrm{NE}$ Brazil granitoids. $\mathrm{SiO} 2$ vs $\mathrm{FeOt} /(\mathrm{FeOt}+\mathrm{MgO})$, axis units are $\mathrm{wt} \%$ (a) and $\mathrm{Fe}+\mathrm{Mg}+\mathrm{Ti}$ vs $\mathrm{Mg} / \mathrm{Mg}+\mathrm{Fe}$ axis units are millications (b). Symbols as in Fig. (11). 
The nature of the igneous source can be constrained using the geochemical signatures of the plutonic rocks. The REE and multi-elements patterns (Fig. 10) suggest genetic processes involving amphibole and possibly garnet. The high LREE contents in granites, granodiorites and quartzmonzonites could be related either to the LREE enrichment of their source materials, or to a low degree of partial melting of the crustal protoliths resulting in garnet and amphibole as residual phases. However, their concentration in HREE (heavy rare earth element); more or less 10 times the chondrite values, does not support the assumption of a source containing garnet. Moreover, the spider diagrams (Fig. 10) show no negative anomaly in $Y$, suggesting that garnet was not involved in the residual phase. Enrichment of LREE, together with depletion in HREE during fractional crystallisation, is compatible with fractionation of amphibole, which tends to concentrate the HREE. The spider diagrams characteristically display negative anomalies for $\mathrm{Ba}, \mathrm{Nb}$ and $\mathrm{Ta}$. These anomalies result either from the low content of these elements in the source, or their retention in the residue during partial melting.

The geochemistry and mineralogy of the granitic rocks reflect not only the nature of the protoliths from which they were derived, but also the dynamic conditions under which magmas were formed, evolved and eventually solidified [43]. Compositional differences of melts produced by partial melting of different source rocks, such as amphibolites, tonalitic gneisses, metapelites and metagreywackes, under variable melting conditions can be visualized in terms of molar $\mathrm{CaO} /(\mathrm{MgO}+$ FeOtotal $)$ vs molar $\mathrm{Al}_{2} \mathrm{O}_{3} /(\mathrm{MgO}+$ FeOtotal) ([39]; Fig. 14). In this diagram, most of the samples of the granite plot in the field of partial melts from metagreywackes while those of granodiorites and quartzmonzonite plot in the field of partial melting from metabasaltic to metatonalitic sources. Similar sources are found to the granitoids from eastern Nigeria and NE Brazil of (Fig. 15). These source rocks are predominantly found in the lower part of the continental crust and we suggest that the source for the granodiorites and quartz-monzonite was metamorphosed lower crustal mafic igneous rocks. The abundance of hydrated minerals (amphibole and biotite) in the plutonic rocks suggests that the melting of the protolith took place under hydrous conditions. The high-K calcalkaline to shoshonitic and metaluminous nature of the Banefo-Mvoutsaha plutonic rocks require a metaluminous and relatively K-rich source [41, 44]. The differences observed in granites can be explained by variations in the degree of mineral fractionations, differences in melting conditions and/or minor variation in source compositions. The low $\mathrm{Rb} / \mathrm{Sr}$ ratios and LREE enrichment of the rocks are probably inherited from the source. Thus, the magmatism of the Banefo-Mvoutsaha plutonic rocks may have involved remelting of a composite basic amphibolitic protolith in the deep crust. The low $\mathrm{Ni}$ and $\mathrm{Cr}$ contents of the rocks are consistent with such a model. The large scale melting of the source rocks could have been favored by high heat flow during Pan-African orogenesis or under plating of mantlederived magmas into the crust.

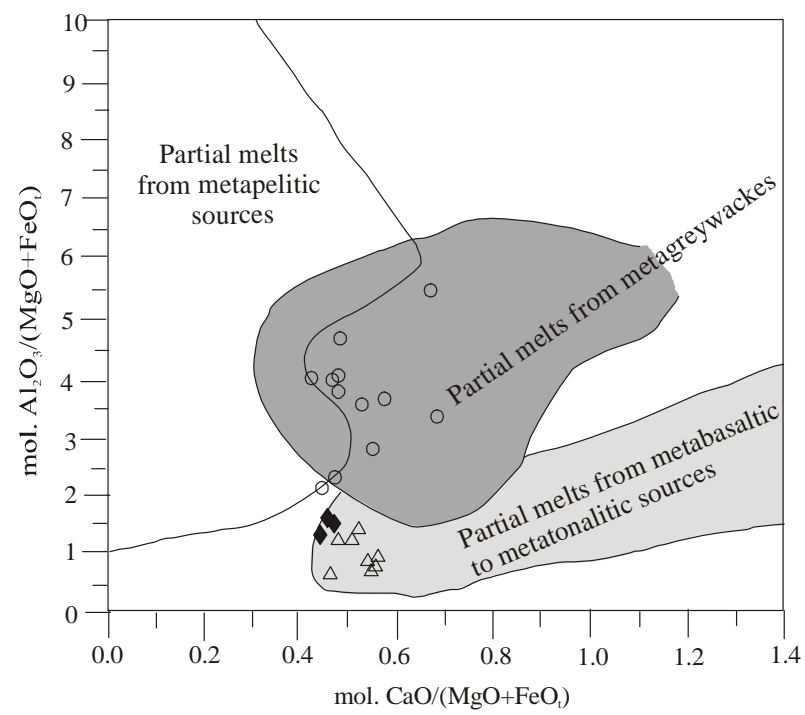

Fig. (14). Molar $\mathrm{CaO} /(\mathrm{MgO}+\mathrm{FeOt})$ vs $\mathrm{Al}_{2} \mathrm{O}_{3} /(\mathrm{MgO}+\mathrm{FeOt})$ for the Banefo-Mvoutsaha granites.

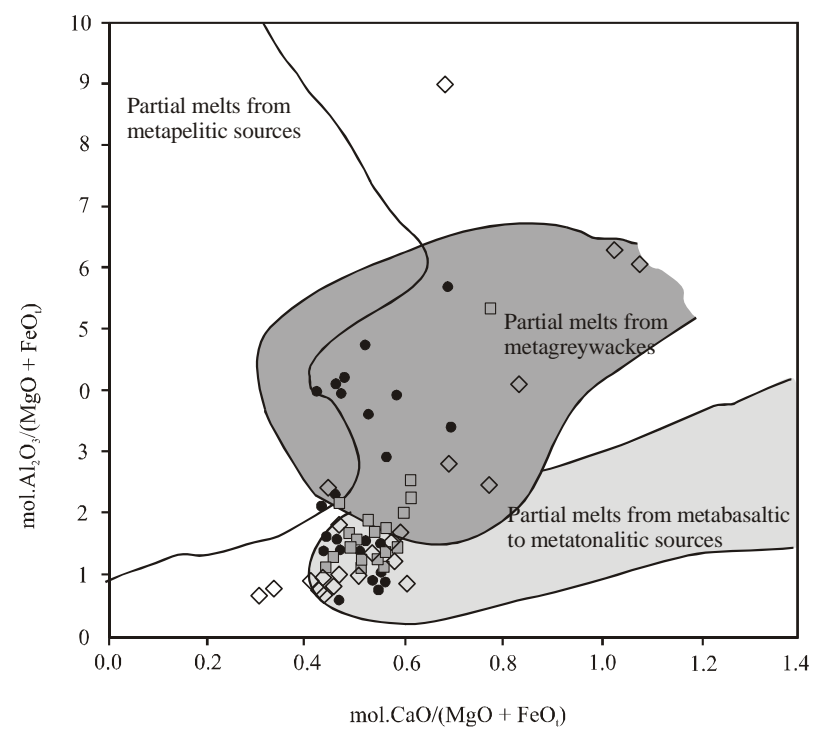

Fig. (15). Molar $\mathrm{CaO} /(\mathrm{MgO}+\mathrm{FeOt}) v s \mathrm{Al}_{2} \mathrm{O}_{3} /(\mathrm{MgO}+\mathrm{FeOt})$ for the Banefo-Mvoutsaha, eastern Nigeria and Borborema Province granitoids. Symbols as Fig. (11).

\subsection{Tectonic Settings}

In the central domain of the Pan-African fold belt in Cameroon, the common distinctive features of the various granitoids from different sampling areas are their depletion in $\mathrm{Sr}$ and $\mathrm{Ti}$, and enrichment in most incompatible elements $(\mathrm{K}, \mathrm{Rb}, \mathrm{Ba})$ compared to highly charged elements, resulting in "fractionated" trends. Overall, trace and REE features point to general characteristics usually attributed to magmatic arc calc-alkaline granitoids; the enrichment in LILE and depletion in HFSE (high field strength elements) such as $\mathrm{Ta}, \mathrm{Nb}$ and $\mathrm{Zr}$ is consistent with the role of crustal 
source component in the genesis of these granitoids [45]. Major element geochemistry of Banefo-Mvoutsaha granitoids also points to the high-K shoshonitic and calcalkaline affinity of the investigated samples, implying a subduction- to collision-related geotectonic setting. These data are consistent with results of previous studies on the central domain plutons. So far, even though almost all major magmatic massifs in this central domain [11, 23, 25] exhibit geochemical features evoking subduction-related magmatism, no other geological evidence for a subduction environment has yet been established. The investigated samples, as other central domain granitoids, differ from common granitoids from magmatic arc [e.g. 45, 46] by their distinctive depletion in $\mathrm{Sr}$ and $\mathrm{Y}$-undepleted pattern. These characteristics, and mainly their high-K calc-alkaline to shoshonitic affinity, are commonly reported in granitoids from late-collision to post-collision continental settings [42, 47]. High-K calc-alkaline granitoids in continental collisional setting evolve to shoshonitic compositions during the late stage (post-collision) of the orogeny where crustal delamination operated [42]. Structural analyses [29] indicate that the Banefo-Mvoutsaha plutonic rocks were emplaced along transpressional $\mathrm{N} 70^{\circ} \mathrm{E}$ early sinistral shear zone $\left(\mathrm{D}_{2}\right)$ resulting in a system of "décrochement-nappe". This shear zone belongs to the main branch of the Central Cameroon Shear Zone which is a major lineament of the Pan-African Orogen in central Africa. The Banefo-Mvoutsaha plutonic rocks share many similarities with some other synkinematic granitoids associated with this Pan-African Orogen in Cameroon [11, 12, 20, 23, 25] and in Brazil [48].

\section{CONCLUSIONS}

1. The Banefo-Mvoutsaha Massif comprises Neoproterozoic magmatic rocks and migmatites gneisses. The main rock units in the massif are granites. All the granitoids have undergone the same deformation observed in the migmatitic gneisses of the basement and both share the same structural patterns. Field relations, petrography and structural observations, point the fact that, these granites are syntectonic intrusive.

2. Plutonic rocks from the Banefo-Mvoutsaha area are peraluminous to metaluminous and conform to I-type granitoids. They are high-K, calc-alkaline to shoshonitic syntectonic intrusions emplaced during the Neoproterozoic event in Cameroon, in close spatial association with the Central Cameroon Shear Zone. They also display less pronounced negative anomalies in $\mathrm{Sr}$ and $\mathrm{Ti}$, and lower $\mathrm{Rb}, \mathrm{Y}$ and $\mathrm{Yb}$ values characteristic of high-K calc-alkaline series.

3. The data in this paper indicate that these three granitic rocks assemblage did not result from the simple differentiation of a common parental magma. The data also suggest that the Banefo-Mvoutsaha plutonic rocks were derived from different crustal protoliths. Major and trace element composition of the granites, granodiorites and quartz-monzonite of the BanefoMvoutsaha Massif are consistent with the magmatism which may have involved remelting of (1) a composite metagreywackes protolith in the upper crust and (2) amphibolitised high-K calc-alkaline basaltic andesites in the central domain of the PANEFB.

4. Our data also suggest that the geochemical differences between the different groups of granitoids in the study area are not necessarily related to changes in the tectonic framework but are more probably due to variations in the mechanisms of magma production in the crust. Besides the source material, water contents and melting temperatures, for example, are known to be critical variables as evidenced by the investigations from Clemens et al. [49] and Johannes et al. [50]. Examples of plutonism in which depletion in water of the crustal source have imposed changes in the melting conditions during subsequent events of production of granitic magmas have been documented by Whalen et al. [51] and Pimentel et al., [46]. In most of the cases, it is likely that the input of heat required to promote large-scale melting of the crust was most probably provided by the introduction of mafic magmas into the crust Roberts and Clemens [41].

5. The plutonic rocks of Banefo-Mvoutsaha area are very similar to other Neoproterozoic high-K calcalkaline syntectonic plutons from western and central east Cameroon in modal, major and trace element characteristics. Roughly similar syntectonic plutonism in relation with lithospheric-scale shear zone is also observed in the Borborema province of NE Brazil, especially close to the Pernambuco shear zone.

\section{ACKNOWLEDGEMENTS}

Thanks are due to Africa Aura Resources Ltd. (Gold \& Iron ore exploration and development company in subSaharan Africa) for providing the first author (Gus Djibril Kouankap Nono: Project Geologist) the possibilities to carry out the research and to pay the geochemical analysis at the commercial ACME Lab, CANADA.

\section{REFERENCES}

[1] V.C. Bennet, and D.J. DePaolo, "Proterozoic crustal history of the western United States as determined by neodymium isotopic mapping", Geol. Soc. Am. Bull., vol. 99, pp. 674-685, 1987.

[2] W.S. Pitcher, "The nature and origin of granite", London: Blackie Academic \& Professional, 1995.

[3] N.B.W. Harris, and S. Inger, "Trace element modeling of pelitederived granites", Contrib. Miner. Petrol., vol. 110, pp. 46-56, 1992.

[4] P.I. Nabelek, and C.D. Barlett, "Petrologic and geochemical links between the post-collisional Proterozoic Harney Peak leucogranites, South Dakota, USA, and its source rocks", Lithos, vol. 45 , pp. 71-85, 1998 .

[5] G. S. Solar, and M. Brown, "Petrogenesis of migmatites in Maine, USA: possible source of peraluminous leucogranites in pluton?" $J$. Petrol., vol. 42, pp. 789-823, 2001.

[6] P.I. Nabelek, and M. Liu, "Petrologic and thermal constraints on the origin of leucogranites in collisional orogens", Trans. R. Soc. Edinburgh: Earth Sci. vol. 95, pp. 73-85, 2004.

[7] J.P. Nzenti, P. Barbey, J.M. Bertrand, and J. Macaudière, "La chaîne panafricaine au Cameroun: cherchons suture et modèle!” In: $15^{\text {ème }}$ Réunion des Sciences de la Terre, Nancy, Société géologique de France, Paris, France, pp. 99, 1994.

[8] J.P. Nzenti, P. Barbey, and F.M. Tchoua, "Evolution crustale au Cameroun : éléments pour un modèle géodynamique de l'orogenèse néoprotérozoïque", In: J. P. Vicat, and P. Bilong, Eds., Géologie et 
environnements au Cameroun. Collection GEOCAM: 1999, pp 397-407, 1999.

[9] J.P. Nzenti, B. Kapajika, G. Wörner, and R.T. Lubala "Synkinematic emplacement of granitoids in a Pan-African shear zone in Central Cameroon", J. Afr. Earth Sci., vol. 45, pp. 74-86, 2006.

[10] T. Ngnotué, J.P. Nzenti, P. Barbey, and F.M. Tchoua "The Ntui Bétamba high-grade gneisses: a northward extension of the PanAfrican Yaoundé gneisses in Cameroon", J. Afr. Earth Sci., vol. 31, pp. 369-381, 2000.

[11] E.L.T. Njiosseu, J.P. Nzenti, T. Njanko, B. Kapajika, and A. Nédelec "New U-Pb zircon ages from Tonga (Cameroon): coexisting Eburnean-Transamazonian $(2.1 \mathrm{Ga})$ and Pan-African (0.6 Ga) imprints", C. R. Géosci., vol. 337, pp. 551-562, 2005.

[12] J.P. Nzenti, E.L. Njiosseu Tanko, and A. Nzina Nchare, "The metamorphic evolution of the Paleoproterozoic high grade Banyo gneisses (Adamawa, Cameroon, Central Africa)", J. Camer. Acad. Sci., vol. 7, pp. 95-109, 2007.

[13] J.P. Nzenti, P. Barbey, J. Macaudiere, and D. Soba, "Origin and evolution of late Precambrian high - grade Yaounde gneisses (Cameroon)", Precam. Res., vol. 38, pp. 91-109, 1988.

[14] J.P. Nzenti, 'L'Adamaoua panafricain (région de Banyo) : une zone clé pour un modèle de la chaîne panafricaine nordéquatoriale au Cameroun", Thèse Doct. d'Etat, Univ Cheikh Anta Diop -Univ Nancy I, France, 1998.

[15] J.P. Nzenti, P. Barbey, P. Jegouzo, and C. Moreau, "Un nouvel exemple de ceinture granulitique dans une chaîne Protérozoïque de collision: les migmatites de Yaoundé au Cameroun", C. R. Acad. Sci., vol. 299, no. 17, pp. 1197-1199, 1984.

[16] A. Nedelec, J. Macaudiere, J.P. Nzenti, and P. Barbey, "Evolution structurale et métamorphique des schistes de Mbalmayo (Cameroun). Implications sur la structure de la zone mobile panafricaine d'Afrique Centrale au contact du craton du Congo", $C$. R. Acad. Sci., vol. 303, pp. 75-80, 1986

[17] J.P. Nzenti, "Neoproterozoic alkaline meta-igneous rocks from the Pan-African North Equatorial fold belt (Yaoundé, Cameroon): biotitites and magnetite rich pyroxenites", J. Afr. Earth Sci., vol. 26, pp. 37-47, 1998

[18] C. Castaing, J.L. Feybesse, D. Thiéblemont, C. Triboulet, and P. Chèvremont, "Palaeogeographical reconstructions of the PanAfrican/Brasiliano orogen: closure of an oceanic domain or intracontinental convergence between major blocks?" Precam. Res., vol. 69, pp. 327-344, 1994.

[19] A. Ganwa, W. Frisch, W. Siebel, G.E. Ekodeck, S. K. Cosmas, and V. Ngako, "Archean inheritances in the pyroxene-amphibolebearing gneiss of the Méiganga area (Central North Cameroon): Geochemical and ${ }^{207} \mathrm{~Pb} /{ }^{206} \mathrm{~Pb}$ age imprints", C. R. Géosci., vol. 340, pp. 211-222, 2008.

[20] M. L. Djouka-Fonkwé, B. Schulz, U. Schüssler, J-P. Tchouankoué, and C. Nzolang, "Geochemistry of the Bafoussam Pan-African Iand S- type granitoids in western Cameroon", J. Afr. Earth Sci., vol. 50, vol., pp. 148-167, 2008 .

[21] G. Njiekak, W. Dörr, J-P. Tchouankoué, and G. Zulauf, "U-Pb zircon and microfabric data of (meta) granitoids of western Cameroon: constraints on the timing of pluton emplacement and deformation in the Pan-African belt of Central Africa", Lithos, vol. 102, pp. 460-477, 2008.

[22] C. Nzolang, H. Kagami, J.P. Nzenti, and F. Holtz, "Geochemistry and preliminary $\mathrm{Sr}-\mathrm{Nd}$ isotopic data on the Neoproterozoic granitoids from the Bantoum area, west Cameroon: evidence for a derivation from a Paleoproterozoic Archean crust", Polar Geosci., vol.16, 196-226, 2003.

[23] T.C. Nguiessi, J.P. Nzenti, E.N. Nsifa, P. Tempier, and F.M. Tchoua, "Les granitoïdes calco-alcalins, syncisaillement de Bandja dans la chaîne panafricaine nord-équatoriale au Cameroun", C.R. Acad. Sci., vol. 325, pp. 95-101, 1997.

[24] G. Tagne-Kamga, E. Mercier, M. Rossy, and N.E. Nsifa. Synkinematic emplacement of the Pan-African Ngondo igneous complex (west Cameroon, central Africa). J. Afr. Earth Sci., vol. 28, pp. 675-691, 1999.

[25] G. Tagne-Kamga, "Petrogenesis of the Neoproterozoic Ngondo plutonic complex (Cameroon, west central Africa): a case of latecollisional ferro-potassic magmatism", J. Afr. Earth Sci., vol. 36, pp. 149-171, 2003.

[26] D. Tchaptchet Tchato, B. Schulz, and J.P. Nzenti, "Electron microprobe (EMP) monazite dating and P-T data of the
Neoproterozoic metamorphic and mylonitic events in the Kekem area, Cameroon North Equatorial Fold belt", Neues Jahrbuch für Mineralogie Abh., vol. 186, no. 1, pp. 95-109, 2009.

[27] S.F Toteu, A. Michard, J. M. Bertrand, and G. Rocci, "U/Pb of Precambrian rocks from northern Cameroon, orogenic evolution and chronology of the Panafrican belt of central Africa", Precamb. Res., vol. 37, pp. 71-87, 1987.

[28] Y. P. Danguene, Nature des protolites et paléo-environnement des métabasites de Mindif (province de l'Extrême Nord au Cameroun), Master Thesis, Univ. Ydé I, Cameroon, 2003.

[29] G. D. Kouankap Nono, Etude du cisaillement centre camerounais dans la région de Banefo-Mvoutsaha (NE Bafoussam). Master Thesis, Univ Ydé I, Cameroon, 2005.

[30] F. Debon, and P. Le Fort, "A chemical mineralogical classification of common plutonic rocks and associations", Trans. R. Soc. Edimbourgh, vol. 73, pp. 135-149, 1983.

[31] B.W. Chappell, and A.J.R. White, "I- and S-type granites in the Lachlan Fold Belt”, Trans. R. Soc. Edinburgh: Earth Sci., vol. 83, pp. 1-12, 1992.

[32] B.R. Frost, C.G. Barnes, W.J. Collins, R.J. Arculus, D.J. Ellis, and C.D. Frost, "A geochemical classification for granitic rocks", $J$. Petrol., vol. 42, pp. 2033-2048, 2001.

[33] J.M. Bertrand, C. Dupuy, J. Dostal, and I. Davidson, "Geochemistry and geotectonic interpretation of granitoids from Central Iforas (Mali, West Africa)", Precamb. Res., vol. 26, pp. 265-283, 1984.

[34] R. Ayuso, and J.G. Arth, "The Northeast Kingdom batholith, Vermon: magmatic evolution and geochemical constraints on the origin of Acadian granitic rocks. Contrib. Miner. Petrol., vol. 111, pp. 1-23, 1992.

[35] R.N. Thompson, M.A. Morrison, G.L. Hendry, and S.J. Parry, “An assessment of the relative role of crust and mantle in magma genesis: An elemental approach", Philos. Trans. R. Soc. Lond. A, vol. 310, pp. 549-590, 1984.

[36] E. C Ferré, R. Caby, J.J. Peucat, R. Capdevila, and P. Monié, "PanAfrican, post-collisional, ferro-potassic granite and quartzmonzonite plutons of eastern Nigeria", Lithos, vol. 45, pp. 255-279, 1998.

[37] A.F.D. Silva Filho, I.P. Guimaraes, M.F.L.D. Brito, and M.M. Pimental, "Geochemical signatures of main Neoproterozoic Latetectonic granitoids from the Proterozoic Sergipano fold belt, Brazil: significance for the Brasiliano orogeny", Intern. Geol. Rev., vol. 39, pp. 639-659, 1997.

[38] B.W. Chappell, A.J.R.White, "Two contrasting granite types", Pacific Geol., vol. 8, pp. 173-174, 1974.

[39] F.F. Altherr, A. Holl, E. Hegner, C. Langer, and H. Kreuzer, "High-potassium, calc-alkaline I-type plutonism in the European variscides: northern Vosges (France) and northern Schwarzwald (Germany)", Lithos, vol. 50, pp. 51-73, 2000.

[40] D.J. De Paolo, "A neodymium and strontium isotopic study of the Mesozoic calc-alkaline granitic batholiths of the Sierra Nevada and Peninsular Ranges, California”, J. Geophys. Res, vol. 86 (B11), pp. 10470-10488, 1981.

[41] M.P. Roberts, and J.D. Clemens, "Origin of high-potassium, calcalkaline, I-type granitoids”, Geology, vol. 21, pp. 825-828, 1993.

[42] J.P. Liégeois, R. Black, J. Navez, and L. Latouche "Early and late pan African orogenies in the Aïr assembly of terranes (Tuareg Shield, Niger)", Precamb. Res., vol. 67, pp. 59-88, 1994.

[43] M.P. Roberts, C. Pin, J.D. Clemens, and J.L. Paquette, "Petrogenesis of mafic to felsic plutonic rock associations: the calcalkaline Quérigut complex, French pyrénées”, J. Petrol., vol. 41, no. 6 , pp. 808-844, 2000 .

[44] K.T. Winther, and R.C. Newton, "Experimental melting of hydrous low-K tholeiites: evidence of the origin of Archean cratons", Geol. Soc. Denmark Bull., vol. 39, pp. 213-228, 1991.

[45] J.A. Pearce, N.B.W. Harris, and A.G. Tindle, "Trace elements discrimination diagrams for the geotectonic interpretation of granite rocks", J. Petrol., vol. 25, pp. 956-983, 1984.

[46] M.M. Pimentel, R.A. Fuck, and C.J.S. Alvarenga, "Post-Brasiliano (Pan-African) high-K granitic magmatism in central Brazil: the role of Late Precambrian-early Paleozoic extension", Precamb. Res., vol. 80 , pp. 217-238, 1996.

[47] R. Black, and J.P. Liégeois, "Cratons, mobile belts, alkaline rocks and continental lithospheric mantle: the Pan-African testimony", $J$. Geol. Soc. Lond., vol. 150, pp. 89-98, 1993. 
[48] V.P. Ferreira, A.N. Sial, M.M. Pimentel, C.A.V. Moura, "Intermediate to acidic magmatism and crustal evolution in the Transversal Zone, north-eastern Brazil", In: V. Mantesso-Neto, A. Bartorelli, C. Carneiro, and B.B. Brito-Neves, Eds., Geologia do continente Sul-Americano: evolução da obra de Fernando Flàvio Marques de Almeida. Beca, São Paulo, Brazil, pp. 189-201, 2004.

[49] J.D. Clemens, and D. Vielzeuf, "Constrains on melting and magma production in the crust", Earth Planet. Sci. Lett., vol. 86, pp. 287$306,1987$.
[50] W. Johannes, and F. Holtz, "Formation and composition of $\mathrm{H}_{2} \mathrm{O}$ undersaturated granitic melts", In: J.R. Asworth, and M. Brown, Eds., High temperature metamorphism and crustal anatexis. Unwin Hyman, London, 1990, pp. 87-105.

[51] J.B. Whalen, K.L. Currie, and B.W. Chappell, "A-type granites: geochemical characteristics, discrimination and petrogenesis", Contrib. Miner. Petrol., vol. 95, pp. 407-419, 1987.

[52] N.M. Evensen, M.J. Hamilton, and R.J. O'Nions, "Rare earth abundances in chondritic meteorites", Geochem. Cosmochim. Acta, vol. 42, pp. 1199-1212, 1978.

(C) Nono et al.; Licensee Bentham Open.

This is an open access article licensed under the terms of the Creative Commons Attribution Non-Commercial License (http://creativecommons.org/licenses/by-nc/ $3.0 /$ ) which permits unrestricted, non-commercial use, distribution and reproduction in any medium, provided the work is properly cited 